\title{
SANITARY QUALITY OF ULASI RIVER, OKIJA, ANAMBRA STATE, NIGERIA
}

\author{
II. J. Anazoo and ${ }^{2}$ S. N. Ibe* \\ 'DEPARTMENT OF MICROBIOLOGY, \\ ANAMBRA STATE UNIVERSITY OF SCIENCE AND TECHNOLOGY, ANAMBRA STATE, NIGERIA. \\ ${ }^{2}$ DEPARTMENT OF MICROBIOLOGY, \\ UNIVERSITY OF PORT-HARCOURT, PORT HARCOURT, NIGERIA.
}

\begin{abstract}
The sanitary and physical quality of four areas of activity in the Ulasi River, Okija, Anambra State, were studied in December 2004, using three samples collected at weekly intervals. The average temperature and $\mathrm{pH}$ values of samples ranged from $27.9^{\circ} \mathrm{C}$ to $29.0^{\circ} \mathrm{C}$ and 6.94 to 7.07 respectively. Total aerobic bacterial load, total coliform count and faecal coliform count were lowest or relatively low at the site for obtaining drinking water with mean values of $3.4 \times 10^{5} \mathrm{cfu} \mathrm{ml}^{-1}, 2.8 \times 10^{2} \mathrm{cfu} \mathrm{ml}^{-1}$ and $5 \mathrm{MPN}$ per $100 \mathrm{ml}$ respectively. The processing site for Manihot esculenta and the laundry site had the highest bacteriological counts. Heterotrophic bacteria isolated included Pseudomonas $s p$., Klobsiella sp., Proteus sp., Escherichia coli, Citrobacter sp., Staphylococcus sp., Micrococcus sp., and Yersinia sp. The observations show that the Ulasi River is not safe for drinking without treatment, according to the WHO International Standard for Drinking Water.
\end{abstract}

Keywords: Faecal coliforms, physical parameters, Ulasi River, Anambra State, Nigeria

\section{INTRODUCTION}

It is a common sight to see villagers swimming or bathing and washing clothes or cars within or beside rivers and streams along the highways in Nigeria. Due to lack of pipe- borne water, these citizens also fetch drinking and cooking water from this body of water and process root crops like Manihot esculenta (cassava) and vegetables like Vernonia amygdalina (bitter leaf). Although the streams and rivers empty into larger rivers and then to the sea and there is dilution effect of debris and contaminants (Akpata, 1975), surface waters are heavily polluted from several sources especially after rainfall (Chukwurah, 2001). Sources of pollution include runoff water from farmlands carrying fertilizers, manure, animal and human waste matter, diesel, gasoline, motor oils from the highways and air and lots of trash from gutters and drainages. With the increasing drought in Northern Nigeria, herds of cattle are commonly seen grazing near rivers and streams and polluting the waters in villages in Anambra State.

Several investigators in Nigeria have assessed the health risks associated with using stream and river water for domestic activities (Aluyi et al., 2003; Okokoyo and Rim-Rukey, 2003; Nwachukwu and Otokunefor, 2003). Nwachukwu and Otokunefor (2003) reported that water samples from the Rumuji stream, Emohua, Rivers

*Correspondence Author: S. N. IBE

E-mail: sibe_ahs@yahoo.com
State; was positive for Salmonella (43.1\%) and Vibrio $(15.3 \%)$ and these observations correlated positively with total coliform counts. Aluyi, et al. (2003) similarly isolated Escherichia, Salmonella, Shigella, Klebsiella and Clostridium perfringens from Ethiope River, Delta State, Nigeria and found the bacteriological qualities to be unacceptable.

The World Health ,Organization (WHO, 1996) provided guidelines for drinking water quality and recommended that no fecal coliform should be found in drinking water. Presence of fecal coliforms or Escherichia coli serves as an indicator for the possible presence of other diarrhea causing pathogens and enumeration of total coliforms which includes Escherichia, Klebsiella, Entrobacter, and Citrobacter is universally applied to assess the sanitary quality of water (Duguid, et al. 1974).

This study was carried out to assess the sanitary quality of the Ulasi River, which is the main water source for the community in Okija area of Anambra State. The river originates from hills in Dikenafi in Imo State and bypasses Osu and Ukpor towns in Anambra State. It flows down to Okija, joins Okposi River, each retaining its color and finally empties into Bonima River in Rivers State. The river traverses the Onitsha -Owerri expressway and the Okija -Nnewi Road.

\section{MATERIALS AND METHODS}

\section{SAMPLE COLLECTION}

Water samples were obtained from four areas of activities along the Ulasi River, at Okija, Anambra 
State. Two sampling sites, one (A) for drinking water and the other (B) for steeping and processing cassava were located at Ubahundara village; the sampling sites for bathing and swimming (C) and for washing clothes/laundry (D) were located in Ubahuokija near the bridge along the Okija-Nnewi Road. Three samples were collected from each site at weekly intervals for three weeks in December 2004.

All twelve samples were collected at a depth of six inches below the water surface at mid-channel using sterile one liter plastic containers. Samples were placed in an ice box and taken to the laboratory for bacteriological analysis and $\mathrm{pH}$ measurement using a Labtech $\mathrm{pH}$ meter. Analysis was done within two hours of collection. Temperature was recorded in situ with a thermometer.

\section{TOTAL AEROBIC BACTERIAL COUNT AND TOTAL COLIFORM COUNT}

Ten fold serial dilutions of water samples were made in sterile physiological saline. For the enumeration of total aerobic bacteria, nutrient agar (Oxoid) plates were used while MacConkey agar (Oxoid) plates were used for total coliform count. Water samples were diluted serially using sterile 1 $\mathrm{ml}$ pipettes and aliquots of $0.1 \mathrm{ml}$ of undiluted sample,

$10^{-1}, 10^{-2}, 10^{-3}$ and $10^{-4}$ dilutions were plated as found appropriate, in duplicate, on the agar plates. Plates were incubated at $37^{\circ} \mathrm{C}$ for $48 \mathrm{~h}$ before counting of colonies.

\section{FECAL COLIFORM COUNT}

The Most Probable Number (MPN) technique using the three tube test with MacConkey broth was employed. Fermentation tubes were inoculated with $10 \mathrm{ml}, 1 \mathrm{ml}$, and $0.1 \mathrm{ml}$ aliquots of the sample in accordance with Standard Methods (APHA, 1995). The tubes were incubated at $44.5^{\circ} \mathrm{C}$ for $24-48 \mathrm{~h}$. Positive tubes producing acid and gas, were used in estimating the presumptive MPN $100 \mathrm{ml}$.

Confirmed test was carried out by transfering a loopful of broth from a positive tube into Brilliant green lactose bile (BGLB) broth, followed by incubation at $44.5^{\circ} \mathrm{C}$ for $24-48 \mathrm{~h}$. The tubes were observed for gas formation.

Completed test was performed by plating a loopful of broth from a positive BGLB tube onto an Eosine methylene blue (EMB) agar (Oxoid) plate. The plates were incubated at $44.5^{\circ} \mathrm{C}$ for $24-48 \mathrm{~h}$. and observed for dark red colonies with metallic green sheen. Stock cultures of the colonies were prepared on Nutrient agar slants and colonies were used for Gram staining and biochemical tests. Biochemical tests performed included the IMViC test. Final faecal coliform or Escherichia coli count as MPN $/ 100 \mathrm{ml}$ was calculated based on the completed test.

\section{IDENTIFICATION OF BACTERIAL ISOLATES}

Cultural characteristics and biochemical tests used in the identification of bacterial isolates were as described by Treagan and Pulliam (1982). Identification was confirmed using Bergey's Manual of Determinative Bacteriology (Holt et al., 1994).

\section{STATISTICAL ANALYSIS}

The standard deviation of the means of the physical parameters at the four sites of activity were calculated (Hirsch and Riegelman, 1992).

\section{RESULTS AND DISCUSSION}

\section{PHYSICAL PARAMETERS PH AND TEMPERATURE}

Table 1 shows the mean values for $\mathrm{pH}$ and temperature at the four sites. The $\mathrm{pH}$ ranged from $6.94 \pm 0.06$ to $7.07 \pm 0.09$ with the highest reading obtained at the cassava processing location and the lowest from the bathing site. Okokoyo and Rim-Rukey (2003) reported lower pH values ranging from $\mathrm{pH} 6.20$ to $\mathrm{pH} 6.50$ for three polluted sections of Orogodo River, Agbor while the unpolluted section had a $\mathrm{pH}$ value of 6.90. The desireable acceptable $\mathrm{pH}$ limits for water for domestic and recreational uses are from $\mathrm{pH} 7.0$ to $\mathrm{pH} 8.5$ with maximum allowable limits of $\mathrm{pH} 6.5$ to pH 9.2 (WHO, 1971). It could be concluded that the Ulasi River has acceptable $\mathrm{pH}$ values at all sites examined.

The mean values for temperature ranged from $27.9 \pm 0.1^{\circ} \mathrm{C}$ to $29 \pm 0.82^{\circ} \mathrm{C}$. The villagers obtained drinking water and swam in the un-shaded areas well exposed to heat of the sun hence these locations had the highest readings of $28.8 \pm$ $0.61^{\circ} \mathrm{C}$ and $29.0 \pm 0.82^{\circ} \mathrm{C}$ respectively.

\section{BACTERIOLOGICAL PARAMETERS}

Table 2 shows that the total aerobic bacterial population was in the range of $1.3 \times 10^{5}$ to $1.03 \times 10^{6}$ cfu $\mathrm{ml}^{-1}$ for all the sites of the Ulasi River. The total coliform bacteria were in the range of 50 to $5 \times 10^{3}$ cfu $\mathrm{ml}^{-1}$ for all sites (Table3) while faecal coliforms were present in the range of 3 to $23 \mathrm{MPN}$ per $100 \mathrm{ml}$ of water (Table4). The mean total aerobic count was lowest at the drinking site $\left(3.4 \times 10^{5} \mathrm{cfu} \mathrm{ml^{-1 }}\right)$ while the highest count of $6.1 \times 10^{5} \mathrm{cfu} \mathrm{m} \mathrm{ml}^{-1}$ was obtained at the cassava 
processing area. This may be attributed to increase in biomass as a result of the fermentation of cassava in the area. Ulasi River is located close to the highway on a sloppy terrain with areas of erosion surrounding it. The road was under construction at the time of the study hence the river had a muddy appearance, polluted by sediments and run off waters from agricultural land and natural and geologic processes (Chukwurah, 2001). The heterotrophic bacteria isolated from the river are shown in Table 5. They included species of Pseudomonas, Klebsiella, Proteus, Escherichia coli, Citrobacter, Staphylococcus, Bacillus, Micrococcus and Yersinia.

TABLE 1 MEAN PH AND TEMPERATURE VALUES OF THREE REPLICATES AT FOUR SAMPLING SITES

\begin{tabular}{l|l|l}
\hline Sampling site & $\mathrm{pH}$ & Temp. $\left({ }^{\circ} \mathrm{C}\right)$ \\
\hline A. Drinking water & $7.02 \pm 0.10$ & $28.8 \pm 0.61$ \\
\hline B. Cassava processing & $7.07 \pm 0.09$ & $28.0 \pm 0.36$ \\
\hline C. Bathing/swimming & $6.94 \pm 0.06$ & $29.0 \pm 0.82$ \\
\hline D. Laundry & $7.04 \pm 0.06$ & $27.9 \pm 0.10$ \\
\hline
\end{tabular}

TABLE 2 TOTAL AEROBIC BACTERIAL LOAD (CFU ML-1) AT FOUR SAMPLING SITES

\begin{tabular}{lcccc}
$\begin{array}{c}\text { Time } \\
\text { (weeks) }\end{array}$ & $\begin{array}{c}\text { Cassava } \\
\text { spot }\end{array}$ & $\begin{array}{c}\text { Drinking } \\
\text { Water }\end{array}$ & Laundry & $\begin{array}{l}\text { Bathing \& } \\
\text { Swimming }\end{array}$ \\
\hline 1 & $7.4 \times 10^{5}$ & $2.5 \times 10^{5}$ & $1.03 \times 10^{6}$ & $9.5 \times 10^{5}$ \\
2 & $3.4 \times 10^{5}$ & $1.9 \times 10^{5}$ & $5.3 \times 10^{5}$ & $3.8 \times 10^{5}$ \\
3 & $7.4 \times 10^{5}$ & $5.8 \times 10^{5}$ & $9.0 \times 10^{5}$ & $1.3 \times 10^{5}$ \\
\hline Mean & $6.1 \times 10^{5}$ & $3.4 \times 10^{5}$ & $8.2 \times 10^{5}$ & $4.9 \times 10^{5}$ \\
\hline
\end{tabular}

TABLE 3 TOTAL COLIFORM COUNT (CFU ML-1) AT FOUR SAMPLING SITES

\begin{tabular}{lcccc}
\hline $\begin{array}{c}\text { Time } \\
\text { (weeks) }\end{array}$ & $\begin{array}{c}\text { Cassava } \\
\text { spot }\end{array}$ & $\begin{array}{c}\text { Sampling sites } \\
\text { Water }\end{array}$ & Laundry & $\begin{array}{c}\text { Bathing \& } \\
\text { Swimming }\end{array}$ \\
\hline 1 & $1.1 \times 10^{3}$ & $2.0 \times 10^{2}$ & $7.0 \times 10^{2}$ & $5.0 \times 10^{3}$ \\
2 & $4.2 \times 10^{3}$ & $6.0 \times 10^{2}$ & $5.1 \times 10^{2}$ & $4.5 \times 10^{3}$ \\
3 & $1.4 \times 10^{4}$ & $5.0 \times 10$ & $2.8 \times 10^{3}$ & $1.9 \times 10^{3}$ \\
\hline Mean & $6.4 \times 10^{3}$ & $2.8 \times 10^{2}$ & $2.8 \times 10^{3}$ & $3.8 \times 10^{3}$ \\
\hline
\end{tabular}

TABLE 4 TOTAL FAECAL COLIFORM COUNT (MPN PER 100ML) AT FOUR SAMPLING SITES

\begin{tabular}{lcccc}
\hline \multicolumn{5}{c}{ Time } \\
(weeks) & $\begin{array}{c}\text { Cassava } \\
\text { spot }\end{array}$ & $\begin{array}{c}\text { Drinking } \\
\text { Water }\end{array}$ & Laundry & $\begin{array}{c}\text { Bathing \& } \\
\text { Swimming }\end{array}$ \\
\hline 1 & 7 & 9 & 23 & 4 \\
2 & 10 & 4 & 7 & 3 \\
3 & 15 & 3 & 11 & 4 \\
\hline Mean & 11 & 5 & 14 & 4 \\
\hline
\end{tabular}

TABLE 5: CHARACTERISTICS OF BACTERIAL ISOLATES FROM RIVER ULASI, OKIJA

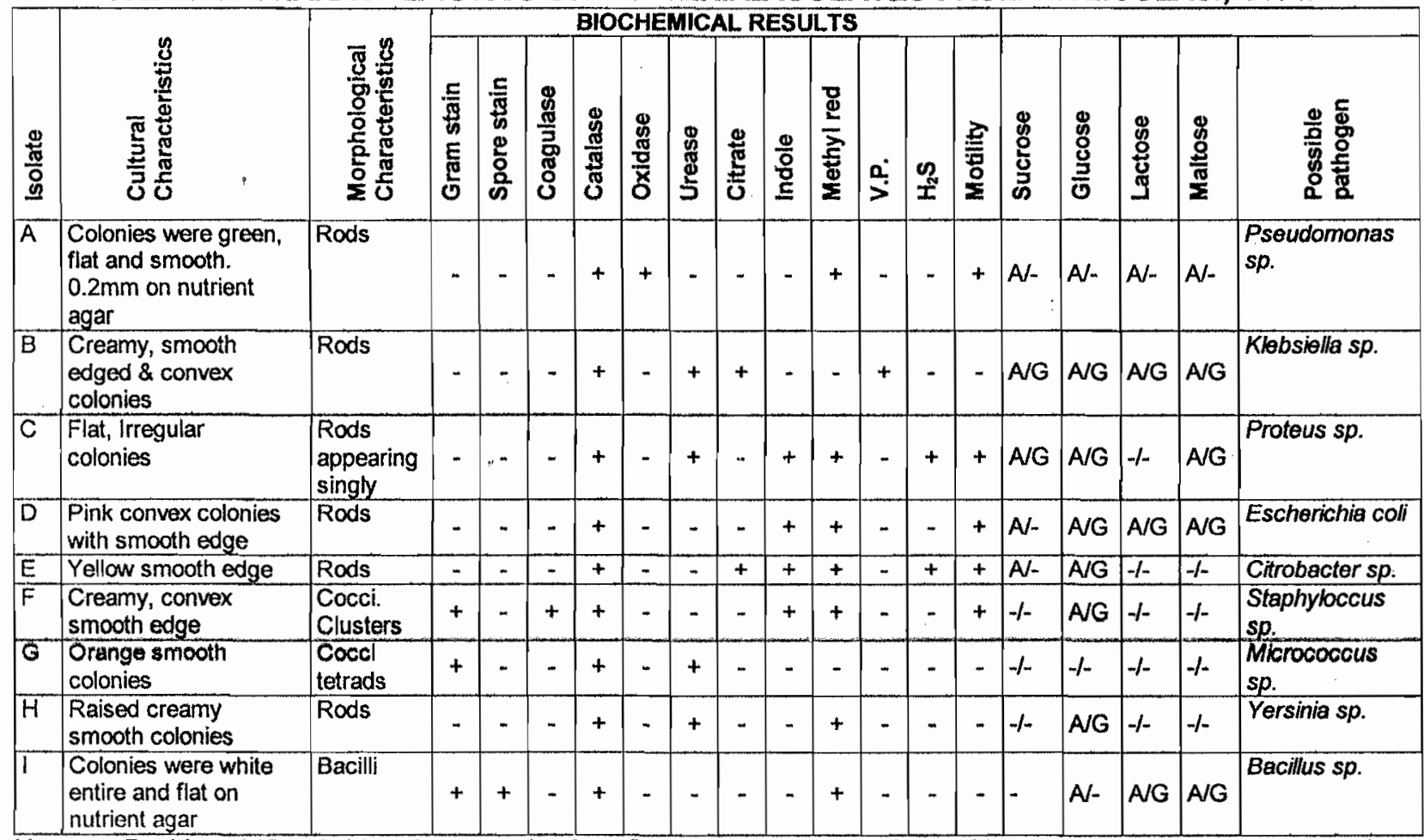

Key: $+=$ Positive, $A / G=$ Acid and gas production, $G=$ gas production only, - = Negative, $A=$ Acid production only. 
The presence of coliforms and other the potentially pathogenic species is cause for concern. The average total coliform count ranged from $2.8 \times 10^{2} \mathrm{cfu} \mathrm{ml}^{-1}$ for the drinking water area to $6.4 \times 10^{3} \mathrm{cfu} \mathrm{ml}^{-1}$ for the cassava processing site. Average faecal coliform count for Ulasi River was lower ( 4 to $5 \mathrm{MPN}$ per $100 \mathrm{ml}$ ) in the drinking water site and bathing site and higher (11 to 14 MPN per $100 \mathrm{ml}$ ) at the cassava processing and laundry sites. Aluyi et al. (2003) also observed lowest $E$. coli count of 2 MPN per $100 \mathrm{ml}$ at the Abraka site where Ethiope River serves as source of drinking water for the community.

It appears that villagers at Okija and other parts of the country use their intuition in deciding the less contaminated sections of the river to obtain water for drinking and cooking, however, these waters do not meet the WHO standard of zero fecal coliform per $100 \mathrm{ml}$ and are not potable. The presence of $E$. coli was indeed indicative of the other pathogens, isolated among the heterotrophic aerobic bacteria. The Ulasi River water should be boiled and filtered or treated before drinking.

\section{REFERENCES}

Akpata, T.V.I. (1975) Studies of abundance, distribution and survival of Escherichia coli in Lagos Lagoon. M.Sc. thesis, University of Lagos, Nigeria.

Aluyi, H.S.A., Atuanya, E.I. and Amoforitse, S.C. (2003) Bacteriological and physicochemical investigations of Ethiope River, Delta State, Nigeria. African Journal of Applied Zoology \& Environmental Biology 5: 29-36.

American Public Health Association/American Water works Association/Water Pollution Control Federation (1995) Standard Methods for Examination of Water $\left(19^{\text {th }}\right.$ ed.) APHA, Washington, DC.
Chukwurah, E. I. (2001) Aquatic Microbiology. Otoba Press Limited. Onitsha, Nigeria.

Duguid, J.P., Marmion, B.P. and Swain, R.H.A (1974) Mackie and McCartney Medical Microbiology $\left(13^{\text {th }}\right.$ ed.). The English Language Book Society and Churchill Livingstone, London.

Hirsch, R.P. and Riegelman, R.K. (1992) Statistical First Aid. Blackwell Science, Cambridge, MA, USA.

Holt, J.G., Kreyg, H.R., Sneath, R. H.A., Standly, J.T. and Williams, S.T. (1994) Bergey's Manual of Determinative Bacteriology $\left(9^{\text {th }}\right.$ ed.). The Williams and Wilken Company, Baltimore, MD, USA.

Nwachukmu, E. and Otokunefor, T.V. (2003) Seasonal changes in the sanitary quality of surface water in a rural community of Rivers State, Nigeria. Nigerian Journal of Microbiology 17: 110-114.

Okokoyo, P.A. and Rim-Rukey, A. (2003) Pollution pattern of Orogodo River, Agbor, Delta State, Nigeria. African Journal of Applied Zoology \& Environmental Biology 5:25-28.

Treagan, L. and Pulliam, L. (1982) Medical Microbiology Laboratory Procedures. W.B. Saunders Company. Philadelphia.

World Health Organization (1971) Intermational Standard for Drinking water $\left(3^{\text {rd }} \mathrm{ed}\right.$.). WHO, Geneva, Switzerland, 15-62.

World Health Organization (1996) Guidelines for Drinking Water Quality, Vol 2. WHO, Geneva. 